\title{
The Persistence of Traditional Gender Roles in Online Shopping App Advertisement
}

\author{
Asnurul Novia Narendra \\ Kajian Budaya Universitas Sebelas Maret \\ Surakarta, Indonesia \\ annarendra@student.uns.ac.id
}

\author{
Sri Kusuma Habsari, \\ Kajian Budaya Universitas Sebelas Maret \\ Surakarta, Indonesia \\ skhabsari@staff.uns.ac.id
}

\author{
Deny Tri Ardianto \\ Kajian Budaya Universitas Sebelas Maret \\ Surakarta, Indonesia \\ denytri@staff.uns.ac.id
}

\begin{abstract}
The form of advertisements of Indonesian online shopping apps changes from display products in 2014 to cultural value display in 2017-2018. This study aims to point out the persistence of traditional gender roles in Tokopedia, despite the changing form of the ads. This study used descriptive qualitative method with semiotics approach by Roland Barthes to find the message and myth about gender role in seven Tokopedia ads. The study shows that while the form of ads have turned into display of cultural values, the rules of gender roles used in the ads remain the same. Even though women in ads are portrayed with the freedom of choice, they remain constrained by beauty myths and norms of society that keep them in second position as subdivision, passive, and consumptive, while men are superior, active, and productive. Although Tokopedia ads have begun to act as a field of business and turn shopping concept from passive consumptive to active productive, users must still shop first as a way to find self- identity, matching business, or ideals. It means the ads forever remains as it is, a public incentive tool to buy something for profit but not to contribute to changes in the norms of society, especially as feminism movement. Keywords : advertisement changes, culture industry, online shopping, traditional gender roles.
\end{abstract}

\section{INTRODUCTION}

Presented as a tool for persuasion, product value adder and a supporting tool for promotional activities [1], advertisements also serve as a guide in showing the prevailing norms or values in society [2], as well as a controller and system builder in community. Advertisements bring are highly influential in encouraging people to consume, affecting the buying behavior, the choosing of objects, as well as the choice of media and the means of purchase, simultaneously building the society's habit [3]. It is because advertisements also acts as a medium which meets the society's need of product information, brand recognition [4], social interaction media, relaxation, pasttime escapism [5] as well as a builder of social status and lifestyle [6].

According to Strinati in Pengantar Menuju Teori Budaya Populer (2003), changes in socio-cultural aspects cause advertisements to change as well. Advertisements no longer display their products directly, but instead they insert the products in a simulation of the society's daily life that reflects the culture approved by the people [7], or through the cultural concept brought by the ads' producer to be consumed by society (unconscious hegemony). Consequently, advertisements do not only result in consumerism practice, but also create norms and rules in the society.

The author find relation between Baudrillard's idea on simulation and hyper-reality, Bourdieu's perception on consumption and cultural capital, and Adorno and Hokheimer's belief on the function and effect of advertisement in society as a product of cultural industry. Baudrillard argued that consumption is no longer aimed to meet one self's needs that are supported by economic factor, but instead it acts as the impact of cultural and social meaning system which is able to push people in choosing commodities [8]. The cultural and social systems are the results of simulation created through from media as like as advertisement. This process built hipper-reality of society's life. Besides, commodities are used by society as a symbolic capital [9], leading them to distinguish themselves, their habits, tastes, and classes from others by consuming symbols of culture [10]. Adorno sees the circumstances as a chance for advertisement to take part in forming rules in society that encourage the people to consume the offered commodities, and gaining profits for capitalists.

One of the rules that is commonly applied in reflecting a society through advertisements is about gender. Gauntlett sees that advertisements strongly reflect inequality in gender role issue [11]. Beauty myth is used as a medium to standardize women's needs, in which the capitalists attempt to provide for them through the commodities they offer. Women's liberty in the selection for themselves is actually a mere simulation of life created by the capitalists which results in false needs for women in their consumption practices [12]. Women in advertisements are portrayed as one who obeys rules and norms despite having freedom to choose what they want to be and have. This results in normality standardization. This is capitalist's reaction towards feminism movement in order to maintain women's position as consumers. This way, they as producers are able to keep creating needs for women, causing them to keep their consumption practices.

Tokopedia, an online shopping application, changed their advertisement form from product display in 2014 to cultural display in 2017-2018. The authors began to observe the phenomenon through Adorno and Hokheimer's perception that positions advertisements as a product of cultural industry entitled as enlightment that actually leads people to ideological grouping. The authors sees that the changes in Tokopedia's advertisement forms is merely the capitalists' new way of encouraging people 
to practice consumption in modern and critical era. Tokopedia attempts to change the image of online shopping from passive-consumptive become activeproductive. It is because shopping with Tokopedia app is depicted as a mean to realize dreams and implement creativities. Although Tokopedia use "freedom" as the tagline and theme for the ads, the authors see that the ads still applies the standard rules and myths that conform traditional gender roles in the society. This indicates that the advertisement still put women in the second position.

\section{LITERATURE REVIEW}

Adorno and Hokheimer argue that advertisements do not serve as a medium that facilitates people to express their aspiration in fulfilling their needs, but as product of culture industry which acts as the social control of the society. Advertisements are born as a guise of the media in covering the real purpose of the ideological business made of a combination of several institutions in terms of actualizing the interests of related parties, which certainly profit- oriented [13]. Advertisements come up along with formation of human's stereotypes, termination of ideas, generalization of living system, and the creation of standard on what is good and bad, supported by media as medium of message distribution [14].

Baudrillard reckoned that media help advertisements simulate society's life as originality, verity, and reality. It leads people to believing that the simulation is the reality of life which must be trusted and imitated. This creates a shift on the value of truth, from the truth that comes from experience to the truth brought by media in the form of symbols. This truth then pioneers the emergence of habitus that distinguishes people from others by their class and life style [15], supported by the consumption practices which form social capital. It is because hyperreality in advertisements eliminates the boundary between truth and simulation [16] and humans' needs no longer come from their own selves, but from capitalist standardization.

\section{PROBLEM STATEMENT}

This study aims to examine the alteration of gender roles in Tokopedia online shopping app advertisements upon the changes in the form of advertisement from product display into cultural display.

\section{METHOD}

This study used seven Tokopedia online shopping app advertisements. They are "Tokopedia, Lebih Lengkap, Lebih Murah, Lebih Aman" published in July 3, 2014; "Jadi Terkenal Dimulai Dari Tokopedia" published in October 1, 2017; "Kejar Jodoh Dimulai Dari Tokopedia" published in September 4, 2017; "Wujudkan Mimpi Senimu, Mulai Aja Dulu di Tokopedia" published in January 15, 2017; "Wujudkan Mimpi Bisnismu, Mulai Aja Dulu di Tokopedia" published in Januari 15, 2017; "Mulai Aja Dulu Hobi Barumu di Tokopedia" published on April 30, 2018; and "Memasak ft Siska Soewitomo, Mulai Aja Dulu di Tokopedia" published in March 11, 2018. The authors used the seven ads because each ad was published in pair in each edition, especially in television commercials. The analytical method used is qualitative descriptive with semiotics approach by Roland Barthes, while the focus is on the meaning of denotation, connotation, and myth to obtain the concept of gender role in the advertisements.

\section{RESULT OF ANALYSIS}

The author found a difference between Tokopedia's online shopping app ads in 2014 and in 2017-2018. In 2014's ads, the product displays comes up with the reflection of Tokopedia's image as an online shopping app that is able to provide more complete product than conventional marketplace does, to provide the best price, and to provide security guarantees against online shopping fraud. Meanwhile, the advertisements in 2017-2018 shows Tokopedia as a shopping app that can help its users to actualize their wishes, dreams, hopes, or even achievements that could not be achieved previously without the help of Tokopedia application. In addition, in 2017-2018, Tokopedia's ads do not encourage people to shop online, but also to start building online business.

By comparing the seven ads, the authors found five changes that distinguish the ad of Tokopedia's ads in 2014 from those in 2017-2018. One advertisement published in 2014 only contains product displays, while the other ads in 2017-2018 contain cultural display (the reflection of society). The 2014 advertisement depicts Tokopedia merely as an online shopping medium, while the 2017-2018 advertisements suggest that Tokopedia is a medium for shopping as well as building business online. The ads from 2014 always separates the use of male and female models in a single ads, while in 2017-2018 the ads put male and female models together in a single ads. The 2014 ads only encourages the viewers to become passive consumers by consuming fashion and electronics products, while the 20172018 ads encourage the viewers to become active consumers by practicing abilities and realizing ideals, desires, hopes, and even great achievements. The last differences is that the 2014 ad only introduces Tokopedia as an online shopping medium that helps people overcome the issues in shopping, such as the difficulty in finding products, best prices, and shopping security even in online shopping. Meanwhile, the ads in 2017-2018 describes that Tokopedia is not just an online shopping application, but also the media of life flexibility that enables the users to get everything in life.

\section{DISCUSSION}

The depiction given by Tokopedia's advertisements is in line with a statement from Adorno and Hokheimer, saying that advertising remains as it is, a cultural industry product labeled as enlightenment, but in fact leads people into a mass deception. It is true that in Tokopedia's ads, the models, representing the audience, are given the freedom to choose and determine what they can consume and which path they can take in order to realize their desires and aspirations. The ads also never seem to question about the gender of the model and its relation with their desired achievement. However, the depicted freedom still encourages women to live and behave in accordance to the prevailing rules, in this 
case is the traditional gender roles. Freedom is actually used by the capitalists to, again, encourage the audience (viewers) of the advertisements to meet the idealized form as standardized through the consumption codes, such as ideal beauty, ideal handsome, ideal establishment, and even ideal success. By creating advertisements with certain types and themes as the packaging that keeps the audience unaware of the ongoing deception [17], the producers invite the reader to keep their consumption practices under the pretext of identity creation or cultural capital as described by Bourdieu, i.e. the symbolic capital in the form of commodities or social capital in the form of network. This way, the duping of the capitalists continues to occur through the produced symbols and cultural products.

The concept of freedom in Tokopedia advertisements is not in the form of independence, but instead a restraint which is not realized by the society. The formation of stereotype for female and male through advertising results in rules and obligations that should be obeyed by the viewers. The rules then become a life simulation that is believed to be true by society, which is in line with Baudrillard's thought.

In Tokopedia ads, women are spoiled with the freedom to do, choose, and be anything for the sake of self-pleasure (passive consumption), but are made oblivious to the desire in equality of positions with men as equal access and production (productive consumption). The producers also place women close to dressing up, cooking, babysitting, farming, sewing, and enjoying the use of the goods they buy as cultural capital and class differentiation. This becomes the formation of a woman's life simulation that advertisement viewers are required to follow. This simulation supports women to fill the position of objects that are feminine, consuming, relaxed, emotional, and passive, which is in accordance with Strinati's thoughts on the impact of advertising on its audience.

As found in the previous research conducted by Parameswari, advertisements create the measurement for ideal body size, ideal beauty, and ideal success that women must embody in order to make men love them and confirm that they are ideal women [18]. On the other side, men are required to be able to fight and be productive in order to meet the concept of superhero and active-productive. This is in line with Gauntleet's thought that advertisements continue to perpetuate the traditional gender concept in which women are housed as housewives, with beauty, family hygiene and the practice of comforting others as their achievements, while men are workers with attaining self-achievement and self-enjoyment.

Simulations of human life with traditional gender roles continue to occur in Tokopedia ads despite the changing in the form of advertisements which becomes nearer to the reflection of modern society's life with all the freedom. As a result, the myths regarding the profession of women and men are utilized as a political tool that places society's power in a patriarchal system, and the built of a fashion pattern makes society obedient to the prevailing hierarchy. This raises the practice of consumption by women for false needs in order to be attractive to men and to achieve ideal beauty measures.
Society grows and learns in a very rapid speed. People understand that using gender issue in advertisements will only perturb feminism. Thus, producers attempt a new strategy to boost people's consumption practices by using the issue of consumption as a representation of class and identity that is capable of generating false needs in encouraging consumption of signs. By showing simulations of life presented as a reality without the existence of reality itself as Baudrillard explained, Tokopedia advertisements demonstrate the false needs of society which can only be fulfilled by spending practices. This is obviously seen in all of the Tokopedia ads in 2017-2018 that make the practice of online shopping at Tokopedia as the first step for people to find ideas, ideals, hidden abilities, business opportunities, even hobbies that can bring profits.

The concept of consumption as an identity formation which is adopted by Tokopedia has been predicted earlier by Du Gay who believes that commodity production is related to the production of context [19]. Parameswari also sees it not only as consumption in the use of products, but also the adoption of meaning. Consequently, the adoption of meaning for the purpose of the formation of self-identity encourages women in Tokopedia advertisements to meet the social standards that are deliberately created and cause the desire to consume. Women do not consume in accordance with their own needs, but the achievement of desire. This proves that the women in Tokopedia online shopping app ads remain in their second position (after men) and patriarchy is still leading.

In the future, if the rules on advertising are consumed by the public with evidence that advertisements in 2017- 2018 are able to attract more people to practice online shopping compared to previous advertisements in 2014, this will prove that the practice of hegemony towards the society by the media is successful. It is because media are supposed to keep perpetuating the status quo of dominant institutions, not merely to complement the needs of small unfavorable parties [20].

The authors considered that the production of ads which features female and male models in pairs is not aimed as gender equality, but gender neutralization. Therefore, advertisement can be made available to all gender and create greater profit opportunities. It just like the ads that deliberately deprive gender stereotypes and promote nonstereotypical pursuits aimed at targeting readers with openminded brands that will create a flexible space for male or female consumers [21]. As a result, the impact of advertising for consumption is not only aimed at women, but also men. This indicates through advertisements, the capitalists do not only target women but also men.

\section{CONCLUSION}

From the above explanation, it can be concluded that the shift from traditional-conventional shopping practices to modern-online and the advertising form of product display to the cultural display that show reflection of people daily life are unable to change the values, ideology, and gender roles in society. The changes that occur are only in the way of shopping and the form of advertising as a medium to 
encourage consumption practices, not deep enough to change the ideology and gender rules in advertising.

Researches find that capitalist' targets in modern era are not only women but men as well. The needs of women and men are equated through symbols that must be consumed for the achievement of standardization measures. Thus, this study was conducted with the aims to be a reminder for the society to keep being actively involved in viewing the prevailing gender roles and not to be a victim of the renaissance duping of cultural products.

From the above facts, the authors find the side that has not been addressed in this paper. It is the impact of advertisement form changes on the society's online shopping practices using Tokopedia application. Moreover, the author sees that feminism is initially against gender inequality, but nowadays feminism and masculinity unite to fight the capitalists in standardizing society through industrial culture products. Thus, it can be an input for further research on the position of advertising media amid growing feminism and masculine rules in the community.

\section{REFERENCES}

[1] Shimp, T. A, Periklanan promosi dan aspek tambahan komunikasi pemasaran terpadu, Jakarta: Erlangga, 2003.

[2] Hadadi, K., and Almsafir, M. K, The impact of online advertising on proton sales among expatriates in Malaysia, Procedia: Social and Behavioral Sciences, 2014, pp. 274-281.

[3] A. G., Ismail, M., Majeed, C. F., and Ghazal, F, Effects of advertisement on consumer's buying behaviour with references to FMCGs in Southern Punjab-Pakistan, Journal of Marketing and Consumer Research, 2016, pp. 22-30.

[4] Abideen, Z. U., Farooq, W., and Latif, A, How urban children process advertising message: special reference to television advertising in Pakistan, African Journal of Bussiness Management, 2011, pp. 3962-3974.

[5] Lee, J., and Lee, H., Canonical correlation analysis of online video advertising viewing motivations and access characteristics, new media \& society, 2012, pp. 13581374.

[6] Kumar, A., and Sharma, R., Perceived influential aspects of TV advertising. Paradigm, 2017, pp. 192-210.

[7] Strinati, D., Pengantar menuju teori budaya populer, Yogyakarta: Bentang Budaya. 2003.

[8] Baudrillard, J. P., Masyarakat konsumsi, Yogyakarta: Kreasi Wacana, 2011.

[9] Lubis, A., Postmodernisme: teori dan metode, Jakarta: Rajagrafindo Persada, 2016.

[10] Swartz, D., The social logic of cultural sistinction, French Politics and Society, 1985, pp. 45-48.

[11] Gauntleet, D., Representation of gender in the past, media, gender, and identity and introduction, London: Routledge, 2002.

[12] Wolf, N., The beauty myth: how images of beauty are used againt women, New York: Harper Perennial, 2002.

[13] Adorno, T. W., and Horkheimer, M., The culture industry: enlightenment as mass deception, In M. G. Durham, and D. M. Kellner, media and cultural studies keyworks, pp. 41-72, Malden: Blackwell, 2006.

[14] Dyer, R., Stereotyping, In M. G. Durham, and D. M. Kellner, Media and cultural studies keywork, pp. 353365, Malden: Blackwell, 2006.
[15] Bourdieu, P., The forms of capital, In J. Richardson, Handbook of theory and research for the sociology of education, pp. 241-258, New York : Greenwood, 1986.

[16] Baudrillard, J. P., The precession of simulacra, In M. G. Durham, and D. M. Kellner, Media and cultural studies keywork, pp. 453-481, Malden: Blackwell, 2006.

[17] Hsuan, T. L., and Yazdanifard, R., The review of the most effective of online advertisement techniques to affect online customer buying decision, global journal of management and business research: E Marketing, 2014, pp. 4-11.

[18] Parameswari, P., Membaca makna di balik tiga iklan produk pencokelat kulit nivea: Representasi kecantikan perempuan di Jerman, Depok: Universitas Indonesia, 2012.

[19] Du Gay, P., Production of culture/culture of production, Great Britain: Bath Press Colourbooks, 1997.

[20] Gunter, B., Measuring cognitive impact of media, London: Sage Publication, 2011.

[21] Mihafrunza, I. F., Ethical aspects of gender stereotypes in Romanian advertising, ESSACHESS, Journal for Communication Studies, 2016, pp. 143-157. 